\title{
The Romanian Literature Complexes in Post-Revolutionary Curricula
}

\author{
Conf.univ. dr. Nicoleta CRÎNGANU \\ Universitatea „Dunărea de Jos” din Galați
}

\begin{abstract}
After the fall of communism in 1989, the Romanian school made a huge effort in order to recover the works that were prohibited during the communist regime. On the other hand there were writers and works who were abandoned by the curricula and the textbooks because of the author's colaboration with the communist authorities. The used criteria were often extra-literary showing the complexes of the Romanian literature in the high shool curricula. The aim of this paper is to show these complexes and how they evolved through the post-communist years by now. The method is a comparative study of the curricula, from the late communist years to the post-revolutionary period.
\end{abstract}

Keywords: literature, curricula, post-communism, complexes, textbooks.

If the Romanian literature evolves, as it has been said [Mihăilescu, 2002] in the context of discontinuities, the school curriculum and textbooks reflects these discontinuieties, both in their didactic construction and in promoting aesthetic dimensions according to the era in which the authors / works have taken interest in. They reflect the structure of the collective mentality, with its obsessions and its complexes, with its imaginary projections or the myth that the collective mentality cultivates. This article proposes a discussion on the Romanian cultural and literary complexes, the way that they can be found in the high school Romanian language and literature curricula and textbooks, starting from the lasts school text of the communist curriculum to the books used for learning (some of them are still used) in the postcommunist period.

One of the remarks that Lucian Boia makes in his book „Why Romania is Different" is that there is "a political and institutional delay correlated with a cultural lateness of the same magnitude" [Boia, 2013: 35]. It gave birth to a inferiority complex, considered by the mentioned author to be "the first illness" of the Romanian society that "discovers its insignificance”, as a small country being ",at the mercy of others" [Boia, 2013: 61], but from which ",an conceited construction is born, designed to counteract the smallness of the present" [Boia, 2013: 61]. In this inferiority complex one can find the roots of the latinist purism, 
the rediscover of the Dacians, the protochronism, the myth of a heroic history and a literature as it is.

Therefore, in close conection to the political and cultural choices the communist and post-communist Romanian literature proposed a series of „identity projects” [Mihăilescu, 2017] that constantly oscillated between Latinist vision (Eurocentrist) and Daco-getic (autochtonous) alternative. Vintilă Mihăilescu, in his study "On Exceptionalism and Its Romanian Hypostases", emphasizes that "the Latinist temptation - and otherwise the Eurocentrist - had to inaugurate the beginnings of the national construction, as it was predictable (if not even necessary to accompany it later) [Mihăilescu, 2017: 50]. The author believes that these tendencies are the expressions of a Romanian exceptionalism, a concept that means exception to a "normative reference” [Mihăilescu, 2017: 45]. According to the mentioned author, the premises of the exceptionalism are the primitive ideology know as the ideology of evolution/progress, autochthonous ideology or the difference and the humanist ideology or the ideology of the universality. The three premises are chronologically successive generally, but they also manifest themselves in synchronicity in contexts requiring identity adjustments. Initiated at the begining of the "national construction", when the conciousness of the peripherical status affects the ego of the Romanian elites, the exceptionalism is reflected in the remarks that Lucian Blaga makes on the major culture ("monumental"), respectively, on the minor culture (ethnograpfic), as a "problem of creators' and community psychology" [Nistor, 2002: 64]. Lucian Blaga's distinction has nothing pejorative, on its direction are Mircea Martin's observations from "George Călinescu and the Romanian literature complexes" using "modulated concepts at the crossroads of the creative psychology with history, of the literature with ideologies, and of the culture with society" [Cistelecan, 2010]. "Organic complexes", generating exaggerations or distorsions associated with a "small, provincial and retarded peripheral culture" [Cistelecan, 2010] revealed in contact with the Western culture, they associate "humble origin" with "delay", "ruralism", "perihery", and "discontinuity", generating an "eternal beginning", a need for European integration conjugated to another - of specification, a delay coming from provincial isolation, a "centripetal vocation," an "autarchic character" [Zamfir, 2011:17].

Without being far from Mircea Martin's perspective, Eugen Negrici emphasizes the retardation of Romanian literature, putting it under the fear of "national fragility" [Negrici, 2008], correlating the political and historical myths with the "atypical evolution of Romanian literature" [Negrici, 2008: 23]. Identity 
complexes have induced the "feeling of emptiness and frustration," of "present or future danger," which, using the "psychological mechanism of compensation", sublimates frustration in "idealization". The mechanisms that set up the compensatory action of idealization would be "the making taboo of the literary heritage", "the overbid of the literate perceived as the defenders of the city" (becoming civilized heroes, guides, legislators, founding parents, providential people, directors of consciences, genius princes, torch bearers, national lights), "the idealization of some literary periods and the overbid of some generations of creation", "mimicry of normality","zeal for synchronization" or obsessions. In the same sense, Mihai Zamfir observes that "because of an explainable complex of inferiority, the Romanian researchers tried to push as far as possible in history the begining of our literature" [Zamfir, 2011: 29] and Alexandra Tomiță argues that protocronism is "one of the more visible and extended incarnations of national-communist mythology" [Tomiță, 2007: 82], in the context in which Romanian literature is "deprecated by the theory of European synchronicity "[Cristea, 2014: 34].

Going forward, on the line of the inferiority complex and frustration related to delay and discontinuity, Eugen Ionescu's observations place the obsessions of Romanian literature in the area of neurosis. He believes that "one of the vices, one of the obsessive neuroses of a literature that offers and refuses at the same time the dialogue with the great civilizations", results from the fear of being unable to show their national and state character, the inability to design a its own policy, in the context of the neighborhood of the three great empires that marked the existence of Romania. Ionescu binds the inability of the Romanians to design their own policy with the inability to generate their "own culture, authentic expression of the ethnic soul" [Ionescu, 1998], apud Iulia Badea-Gueritee. Quoting Eugen Ionescu, Iulia Badea-Gueritée explains why Romanian literature is not portable in a correspondence with "România literară". The author believes that the Romanian writers are the victims of another complex, "the imposibility of the translation of the language," which makes the authentic soul wither in a foreign language.

If, in the terms of Vintila Mihăilescu, the remarks of the above mentioned authors are under the sign of a "recuperative exceptionality" [Mihăilescu, 2017: 63] (criticized for "the overestimation of the Romanian peasant, Latinity or (...) to the constant ingredient of an exemplary orthodoxy" [Mihăilescu, 2017: 63]), there is also a "defeatist exceptionalism" [Mihăilescu, 2017: 66] which is lacking the mobilizing character, the authors doing nothing 
else but to observe the weaknesses of Romanian literature, suggesting the feeling of one's own greatness.

Vintilă Mihăilescu reminds about Emil Cioran, who in „Schimbarea la față a României" complains about the fact he was born in a second hand country, where the lucidity becomes tragic. In the same manner, Bogdan Petriceicu Hasdeu criticized the provincial status of the Romanian literature, which he said was anachronistic and written by mediocre writers, as Mihai Zamfir informs. Whether are we talking about recuperative or defeatist exceptionalism, one can observe that this generates myths and complexes, discontinuities and timing tendencies, that goes through the entire Romanian literature. They are materialized in the school textbooks, by the contribution of Titu Maiorescu and his theory (,teoria formelor fără fond), respectively, by Eugen Lovinescu and his theory of synchronicity. The complexes and the myths have entered in the school textbooks, but at the same time they turn the textbooks into ways of (self)perpetuation, due to the fact that the literature studied in school affects the collective mind.

Communists must have agreed this approach of culture / literature greatly by the great Romanian spirits, because its centripetal vocation favored the cultural isolationism promoted in the first years, the protoconism and the push away, in history, of the literary beginning fed the dictator's nationalist obsessions, and the political/historical delay motivated the material or cultural deprivation.

The curriculum and the school textbooks (that were unique) from the last years of the communist era are the expression of a recuperative exceptionalism that was used by the regime as a mobilizing tool, even if it came from a inferiority complex. Thus, in the 9th grade of high school students began to study the Romanian literature with the "origin and development of the Romanian language", where they insist on the Latin character, in order to exult the same noble origin invoked by the "S,coala Ardeleană". The next chapter of the 9th grade curriculum and textbook was intended to the folkloric literature, then the authors suggest that the students start the study of the Romanian literature from its begining, "the old Romanian literature". The students studied mostly the Moldavian chroniclers, Grigore Ureche (in whose work the art of the portrait was explored, with a special focus on Stephen the Great, presented in a mythical light), Miron Costin (studied for the „De neamul moldovenilor...", important for the emphasis on the Latin origin of the Romanians) and Ion Neculce. The historiography was studied using the language and literatures' development key, in other words, in term of evolution and progress, that 
remind of the exceptionalism's "primitivist ideology” as Vintilă Mihăilescu writes. The way that Dimitrie Cantemir was presented in the school textbooks, as „multilateral personality of the Romanian culture and literature” reminds of Eugen Negrici's "factory of saints", because, even if Cantemir deserves this characterization his writings did not enter the public consciousness until very late. Yet the high school students weren't told about this fact, so they might believe that Cantemir could be the angular stone of the Romanian literature.

Later, other authors were studied in the same key: Mihai Eminescu, Ion Creangă, Ion Luca Caragiale (studied under the sign of their contribution to the universal literature), and the literary periods are considered evolution periods: for the Școala Ardeleană (Transylvanian School) one pursues the movement's contribution to the development of the language and literature, in the case of "1948 moment" the authors suggested a new begining of the literature, through the directions suggested by „Dacia literară” and Mihail Kogălniceanu (Romanian mythology, history, the nature of the homeland, through Ion Heliade Rădulescu, Costache Negruzzi or Vasile Alecsandri). The 10th grade curriculum and textbbook emphasizes the rural dimension of the Romanian society, through the study of some authors as George Coșbuc („Zamfira's Wedding” - „Nunta Zamfirei”), Octavian Goga („Prayer”- „Rugăciune”), Mihail Sadoveanu („The Hatchet” - „Baltagul”), Tudor Arghezi („Galore” - „Belșug”), Liviu Rebreanu („Ion”), followed by Zaharia Stancu („Barefoot” - „Descult,") or Marin Preda (Moromeții"), in the context of "contemporary tendencies in Romanian literature" as the authors called the poswar literature. A theme as history was used to emphasize heroic characters as Stephen the Great in Barbu Ștefănescu Delavrancea's "Sunset”, in the context of a recuperative and mobilizing exceptionalism.

The curriculum and the 11th grade school textbook puts the entire Romanian literature under the sign of a glorious mythology. Thus, the students learned what the myths are, but not in order to dismantle the obsessions of the collective mind, but to reconfigure them in the grid of fundamental structures, that served very well to the regime - the myth of "Miorița (mitul transhumanței - reflecting the relationship with the death), the myth of the artist (the relationship with the creative art), the myth of the Flyer (Zburătorul - the love), the ethnogenetic myth (grounding the legendary birth of the Romanian people on an ancient myth that puts love at the center of the cosmos). The fundamental myths depicted by George Călinescu in his monumental "History of Romanian Literature" are significantly correlated with works reflecting them (for example Lucian Blaga's "Meșterul Manole"), suggesting this way that the national myth 
would represent the substance that loads the entire Romanian literature. For a more persuasive representation of the national myth, the textbook also suggests the work of Alexandru Phillippide, "Prometheus chained” („Prometeu înlănțuit"), where an universal myth is used, but not any myth, but an heroic myth that emphasizes the need for heroes and civilization, for a saviour hero. At a thorough analysis, this could also lead to the mobilizing exceptionalism. The curriculum and the textbook return then to the beginings of the Romanian literature, pushing them into a historiographical past, where one could find the roots of the fiction literature. The authors write about a Romanian humanism whose first works would be contemporary with European humanism, through Nicolaus Olahus, chosen not only for his noble descendancy or for his correspondence with great European personalities, but also because he underlines the Romanian's language unity. The humanism of the Romanian voivodes is put in the key of the defense of Europe by the Ottoman feudal power [Olteanu, Pavnotescu, Micu, coord, 1983: 36], in the spirit of an obsessive myth of the Romanian culture that always has the feeling of a diffuse danger, of which it feels the need to protect itself [Negrici, 2010: 7]. In this sense, if age was not enough in order to use it in the nexus discourse, the Romanian literature texbooks also grasp the Slavonic language texts, such as "The teachings of Neagoe Basarab to his son Theodosius", ennobled by the comparison with Machiavelli's "The Prince". Moreover, in the context of the humanistic reflex, the Romanian language and literature textbook emphasizes the double quality of the Romanian rulers - one is that of great rulers, rescuing heroes in a national mythology, doubled by another, that of great scholars. This double quality which begins with Stephen the Great, which is said to be "the originator of one of the first works on the history of Moldova", ends with Dimitrie Cantemir [Olteanu, Pavnotescu Micu, eds, 1983: 36].

Even if a fictional vocation one can identify in the old Romanian literature, through Ion Neculce, who, in the excellent analysis of Nicolae Manolescu [Manolescu, 1991, collating information, listening to and reproducing legends, reporting subjectively to historical reality, the Romanian language and literature school textbook as well as the curriculum, did not lean on this dimension, insisting on the Latin origin of the Moldavians, postulated by Grigore Ureche, reinforced demonstratively by Miron Costin and Dimitrie Cantemir, in order to extend the meaning of Romanian humanism to the level of what is called "paşoptism” (1848 moment) or to the twentieth-century literature. The same handbook later invokes the existence of a Romanian Enlightenment through the Școala Ardeleană (Transylvanian School), valuing in this sense the 
"Tiganiada" („The Epic of the Gypsies of Ion Budai Deleanu, where the authors easily pass over the compositional and ideological complexity of the text, relying on what the manual calls "the Enlightenment Ideas". [Olteanu, Pavnotescu Micu, eds, 1983: 58].

In order to neutralize the peripheric status of the Romanian literature, the school textbook also suggests the idea of a Romanian classicism, which they identify in the poetry of the Văcărescu poets, in the comedies of Vasile Alecsandri, the fables of Donici or Alexandrescu, the "characters" of Mumuleanu, the epistles or satires of Grigore Alexandrescu, all of those are linked (from the handbook's point of vue) to the French classicism. At the same time, in the line of Călinescu's exegesis the school textbook searches for a Romanian romantism, that coexists with the classicism, in the fourty-eight context. The forty-eight and post-forty-eight texts use exceptionalist myths and obsessions, from the recuperative - mobilizing ones („Despot - vodă” by Vasile Alecsandri, on the line of "The Flyer” of I.H. Rădulescu, but processing different myths) to the defeatist texts (through Grigore Alexandrescu's satire or the comedies of Mircești poet). Even in the case of Mihai Eminescu, if we remove propagandistic - manipulating slag, one can discover elements of mobilizing exceptionalism in the poem "Emperor and worker" („Împărat și proletar") respectively a defeatist vocation in "Letter I" (,Scrisoarea I"), analyzed and explained as such by the satirical emphasis of the last part, to insist on the quality of Eminescu's national poet, to which the authors add, without any arguments in the handbool, the universal poet [Olteanu, Pavnotescu, Micu, coord, 1983: 147]. This last assumption deserved a better treatment as the contribution of the most important Romanian poet should have been analyzed in terms of universality, so that Romanian students understand the place of the Romanian culture in the world literature.

Surprisingly for a rigorous didactic handbook, whose main criterion for the distribution of authors and works is the chronological order, Mihail Sadoveanu is placed before Creangă and Caragiale, but the myth subordinates the history in the communist school textbooks and a novel as "Brothers Jder" („,Frații Jderi") passes before "Childhood Memories" or the "In Time of War" short story. The violation of the chronological criterion results from the need to establish integrative principles by forcing a sui generis and almost contemporary realism with Balzac but with a vulgar interpretation of realism, not in the spirit of the literary trend whose father is the author of the "Human Comedy". Only after the two authors mentioned previously, which the manual suggests that they are forerunners of a true Romanian realism, the manual 
focuses on the novels of Liviu Rebreanu, but not on "Ion", studied in the 10th grade, without claiming to be in realistic literature. The realism is illustrated through „The Revolt” („Răscoala”). The propaganda's goal is visible here: the novel "Ion" could not be associated with the mimetic vision of the Romanian village, prevented by the parvenitism of the character, but the "Revolt", with the suggestion of the mass movement generated by "exploitation" was, from this point of view, the perfect manipulating mirror of the village.

In the poetry (the 12th grade) the authors give more than necessary space to the symbolism. The authors mention all the poets to whom one could find any trace of symbolist vocation, from the theorist Alexandru Macedonski (introduced in the handbook with a rather romantic text,"The Night of December" - "Noaptea de decembrie”), to Dimitrie Anghel, Ion Minulescu to reach at last George Bacovia. The examples could continue with different approaches to the poetry and the postwar literature, but the main complexes come from the use of George Călinescu's synthesis in the school texbooks, so the postwar literature is freer of such complexes.

In almost thirty years of postrevolutionary culture, the Romanian literature curriculum stood under the sign of reviews and reconsiderations in an attempt to impose a communism free canon, not only in his letter (works and writers), but also in its spirit (a triumphal vision of Romanian writings). Therefore the Romanian language and literature curriculum, but especially the textbook written for the study by the pupils want to discharge the Romanian literature from ideology, to make the school canon more flexible, through the adoption of some writers who had previously been outside it, such as Mircea Eliade and Vasile Voiculescu (this last author was included in the 8th grade textbook with a peripheric work, "A Hymn to the Work" - „Imn muncii”, but after 1989 Voiculescu is studied through his sonnets and the fantastic prose). The authors also added diaspora works and authors who had been forbidden during the communist regime, from Grigore Vieru and Ioan Druță, to Emil Cioran and Eugen Ionescu.

The postrevolutionary curriculum preserves the chronological approach of the Romanian literature until the publishing of the alternative handbooks (associated with a new curriculum in 1998). Feeling the need for a theoretic background for the cultural construction, the 9th grade school textbook begins with some stylistic notions and literature theory. Then the problem of language origin is followed by the roots of the literature, the old Romanian literature, and the vision is almost the same of the one in the communist period, apart from the the propagandist-manipulating intention that lacks. Still, one cannot mention 
important differences neither in the study of the Moldavians chroniclers, nor in Dimitrie Cantermir's or that of Ion Budai Deleanu, the collective mentality preserving its complexes and frustrations. Thus, Stephen the Great portrayed by Grigore Ureche is analysed as one of a great hero, a saviour, situated under a mythicized intention. Neculce is placed under the interpretation of a "first folklorist" and Ioan Budai Deleanu remains as a sui generis enlightener.

The main complexes could be observed in the way of representing the writers of Junimea in curriculums and hanbooks, where the authors emphasize the autochthonous vocation of Titu Maiorescu which is not opposed anymore to C. D. Gherea, as it was in the old curriculum. In exchange, Ion Creangă is placed in a romantic turmoil, thorugh his story tales, even if the authors insist on the demystifying vocation, without naming it. Even so, the students learned about the traditional tale's structures combining this point of view with a raillery intention. The need for timing leads to interesting comparisons, to Rabelais, for example, still coming from George Călinescu's „History of the Romanian Literature".

For Ion Luca Caragiale, the authors of the still unique handbook suggest a vision that place the drama writer in the of anticipation of modern theater, through the "man without qualities", "the theater in theater", corresponding to a need of "burning stages" about Mircea Martin writes. In the same manner Mihai Eminescu is also presented, by showing a subtle symbolist lineage which could be observed in a text as "Melancholy".

From this point of view, the most interesting handbook is the 12th grade Romanian Language and Literature handbook. Published in 1993, it was the work of a group of authors that brought a lot of forgot, forbidden previously or ignored writers [Gligor și urm., 1993]. The book starts with Mircea Eliade, presented as a "complex personality of the Romanian culture", in the context of a monographic approach, followed by Vasile Voiculescu, whose poetry universe is studied, with some examples from the sonnets and the prose. Literary Historians, reviewers, theorists are more than in the previous period, the essay and the essayist became objects of the postrevolutionary study. The postwar literature suggests more and diverse writers, from Marin Preda or Eugen Barbu (previously studied in school), to Petru Dumitriu, Sorin Titel, Ion Druță, Nicolae Steinhardt, Radu Petrescu that were not included in the school study previously. Still ,the handbooks were beautified here and there, some writers were brought in the primary interest of the school, writers that were already in the graces of the elite of our critique" informs Eugen Negrici [Negrici,2010: 7]. This could be a problem not only from the canon point fo view, but from the 
main complexes of the literature also, because, if the objective analysis lacks, these complexes tend to perpetuate. The way that the authors analyze some of the writers remind of an old complex, that of "burning stages”: for example, writing about Mircea Eliade, Andre Gide is mentioned, when about Emil Botta, Edgar Poe, Nerval, Rimbaud etc. The same complex can be mention when the school curriculum and the textbooks include some writers that didn't write in Romanian: Elena Văcărescu, Panait Istrati, Martha Bibescu, Peter Neagoe, Eugen Ionescu (with some works written in french). Mentioning these writers shows the need of international recognition as a complex of the Romanian literature and curriculum.

After 1998, the curriculum and the handbooks changed radically. They changed the focus on contents with the focus on objectives, then on skill. The literature becomes a tool for language and communication learning, the literary works are not the main part of the curriculum anymore. The handbooks do not create literary myths anymore, as the curriculum abandoned the monographic study of the writers. The approach is supposed to be cultural, theoretical and of value [Borza, 2013: 110]. Yet the literature wins a lot from this approach because it favors a larg cultural study, aiming to discover the "mentalities, the spirits of the periods, ages' gusto" [Borza, 2013: 110], trying to recover the great European models, tempting again the timing with the Western literature as motifs of national pride. However the complexes resist in the study of the language's origin, the begining of writing in Romanian (with the Neacșu's letter), the first prints. For the first artistic works some of the books present the „popular books", like the "Flower of gifts" (translated from italian) and for suplementary reading under the title of "The beginings of the Romanian literature", the handbook proposes a text from Publius Ovidius Naso. With a text of Gheorghe Asachi, the student should find out about the "image of the ideal stronghold" linked to Vasile Alecsandri and his „The Song of Latin Stemma”. The same legendary approach can be mentioned in the study of Mihai Eminescu [Iancu, Bălu, 2006]. The curriculum and the textbooks request the study of the Romanian literature in the key of cultural tendencies investigated through case studies. Their title remind of the concern for discussing the complexes: „Latinity and Dacianism", "Religious dimension of the existence", "The role of the literature in the fourty-eight period", "Romanian literature between East and West" etc. Some of the handbooks tend to keep the old work and authors in study, as Lucian Blaga („Eu nu strivesc corola de minuni a lumii” - „I don't crush the petal cup of magic of the world”), Tudor Arghezi („,Testament” - The Will"), Ion Barbu, and this is a sign that the authors tend to remain under some 
literary complexes [Dobra, Halaszi, Kudor, Medeșan, 2007]. Some of the handbooks put the case study under some larger ideas, as "Between history and myth" (the latinity and Dacianism case study), or "Literature - the way to a modern nation" showing the complexes of the society and culture [Martin, eds, 2006].

Even with the change of the Romanian language and literature curriculum, the textbooks still preserve the complexes, from the noble origin, to the "burn of the stages", and above all, the complex of a small languages that makes the authors to include in the didactic canon some writers whose works are in other languages then Romanian as if the literature we have is not enough or not enough famous. That is why Cosmin Borza observes that ",any attempt of reforming of the perceptual dogmas is met exclusively by the intensified and diversified resuscitation of the mitization" [Borza, 2013: 76].

The specificity of the ideas, complexes and obsession is that tend to resuscitate under different shapes. The complexes of the Romanian literature remain in the new school textbooks, even if the school curriculum doesn't favor them anymore. The themes of the study, the approach of the authors and works, the discover of the great ideas of different ages, all of them remain in the study of the literature, even if lately they are questioned and analyzed. But what remains if we abolish myth with all of these assumed complexes? Do we still keep our own identity?

\section{Bibliografie}

Volume critice

Boia, Lucian, De ce este România altfel?, Humanitas, București, 2013

Cristea, Dan, Citind cărțile de azi, Polirom, București, 2014

Ionescu, Eugen, "Littérature Roumaine" suivi de "Grosse chaleur", Fata Morgana, 1998

Manolescu, Nicolae, Istoria critică a literaturii române (vol.I), Minerva, București, 1990

Martin, Mircea, George Călinescu și complexele literaturii române, Albatros, București, 1981

Mihăilescu, Florin, De la proletcultism la postmodernism, Pontica, Constanța, 2002 
Mihăilescu, Vintilă (coord.) De ce este România altfel? Avatarurile excepționalismului românesc, Polirom, București, 2017

Negrici, Eugen, Iluziile literaturii române, Cartea Românescă, București, 2008

Negrici, Eugen, Literatura română sub comunism. 1948 - 1964, Polirom, 2010

Tomiță, Alexandra, „O istorie glorioasă. Dosarul protocronismului românesc”, Cartea Românească, București, 2007

Zamfir, Mihai, Scurtă istorie a literaturii române. Panorama alternativă a literaturii române, Polirom, București, 2011

Periodice

Badea-Gueritée, Iulia, „Este literatura română intransportabilă”, România literară, nr. 45/2005

Cistelecan, Alexandru, Cultura, noiembrie 2010, nr. 300

Cliveț, Nicoleta, The Aesthetic Resurgence of the Post-war Romanian Criticism, Bulletin of the Transilvania University of Braşov, Vol. 3 (52) - 2010

Nistor, Eugeniu „Lucian Blaga: apropieri și disocieri între cultura minoră și cea majoră", Diacronia.ro, accesat la 4 mai 2018.

Programe și manuale școlare

*** Programa de limba și literatura română - clasele IX - XII, 1998, 2006

Costache, Adrian, Ioniță, Florin, Lascăr, M.N., Săvoiu, Adrian, „Limba și literatura română. Manual pentru clasa a XI-a", Art, București, 2008

Crețeanu, Florin, Andronache, Dumitru, Nicolae I., Nicolae, „Limba și literatura română. Manual pentru clasa a XII-a", EDP, București, 1987

Crișan, Alexandru, Papadima, Liviu, Pârvulescu, Ioana, Sâmihăian, Florentina, Zafiu, Rodica, „Limba și literatura română. Manual pentru clasa a X-a”, Humanitas, București, 2005

Crișan, Alexandru, Papadima, Liviu, Pârvulescu, Ioana, Sâmihăian, Florentina, Zafiu, Rodica, „Limba și literatura română. Manual pentru clasa a XII-a”, Humanitas, București, 2002

Davidoiu-Roman, Anca, Paraipan, Luminița, Stoica, Dumitrița, „Limba și literatura română. Manual pentru clasa a IX-a", Paralela 45, Pitești, 2013

Dobra, Sofia, Halaszi, Monica, Kudor, Dorina, Medeșan, Luminița, „Limba și literatura română. Manual pentru clasa a XI-a", Corint, București, 2006 
Dobra, Sofia, Halaszi, Monica, Kudor, Dorina, Medeșan, Luminița, „Limba și literatura română. Manual pentru clasa a XII-a", Corint, București, 2007

Gheorghiu, Vladimir, Nicolae I., Nicolae, Manolescu, Nicolae, Otobâcu, Constantin, „Limba și literatura română. Manual pentru clasa a IX-a”, EDP, București, 1987

Grigor, Andrei, Iancu, Marin, Ilian, Aurelia, Neagoe, Elena, Nebunu, Mihai, Nicolae I., Nicolae, Olteanu, A. Gh., Pavel, Lucian, Roșca, Elisabeta, „Limba și literatura română. Manual pentru clasa a XII-a", EDP, București, 1993

Iancu, Marin, Bălu, Ioan, „Limba și literatura română. Manual pentru clasa a XIa",Corint, București, 2006

Leahu, Emil, Parfene, Constantin, „Limba și literatura română. Manual pentru clasa a X-a", EDP, București, 1981

Manolescu, Nicolae (coord.), „Limba și literatura română. Manual pentru clasa a XI-a", Sigma, București, 2001

Martin, Mircea (coord), „Limba și literatura română. Manual pentru clasa a XIa", Art, București, 2005

Olteanu, A. Gh., Pavotescu, Maria, „Limba și literatura română. Manual pentru clasa a XI-a", EDP, București, 1983 